\title{
A Comparative Study on the Adsorption of Two Remazol Dyes on Green Adsorbent
}

\author{
ESZTER RAPO ${ }^{1,2}$, KRISZTINA JAKAB ${ }^{1}$, KATALIN POSTA ${ }^{2}$, MARIA SUCIU ${ }^{3}$, \\ SZENDE TONK ${ }^{1 *}$ \\ ${ }^{1}$ Environmental Science Department, Sapientia Hungarian University of Transylvania, 4 Calea Turzii, 400193, \\ Cluj-Napoca, Romania \\ ${ }^{2}$ Institute of Genetics, Microbiology and Biotechnology, Szent István University Pater Karoly no. 1, 2100 Godollo, HU \\ ${ }^{3}$ National Institute for Research and Development of Isotopic and Molecular Technologies, Electron Microscopy Integrated \\ Laboratory, 67-103Donath Str., 400293, Cluj-Napoca, Romania
}

\begin{abstract}
Due to the large amount of wastewater discharged by the textile industry, many alternative researches have been undertaken in recent years to effectively remove textile dyes from water. In our study, the adsorption from aqueous solution of two important textile dyes, reactive azo dyes Remazol Red (RR) and Remazol Blue (RB) was studied with calcined chicken eggshell (Gallus Gallus domesticus) adsorbent. Batch biosorption studies were conducted to evaluate the effect of various parameters, such as contact time, initial dye concentration, amount of adsorbent, and $\mathrm{pH}$, to determine the optimal adsorption parameters (Remazol Brilliant Red F3B: $C_{i}=20 \mathrm{mg} / \mathrm{l}, 1.5 \mathrm{~g}$ adsorbent, $160 \mu \mathrm{m}$, $700 \mathrm{rpm}, \mathrm{pH}=6.0 \pm 0.2, \mathrm{~T}=20 \pm 2{ }^{\circ} \mathrm{C}$, where $E \%=97.3$; Remazol Brilliant Blue $R: C_{i}=20 \mathrm{mg} / \mathrm{l}, 1.5 \mathrm{~g}$ adsorbent, $160 \mu \mathrm{m}, 700 \mathrm{rpm}, \mathrm{pH}=6.0 \pm 0.2, \quad T=20 \pm 2^{\circ} \mathrm{C}$, where $\left.E \%=98.8\right)$. The changes in morphological structure were evaluated by SEM analysis. The experimental isotherm data were analyzed using the Langmuir, Freundlich, Dubinin-Radushkevich and Temkin isotherm models. Biosorption kinetics data were tested using pseudo-first-order, pseudo-second-order, where in our experimental conditions the biosorption followed a pseudo-second-order reaction. EDS analyses were carried out, and bioconcentration factors were calculated before and after adsorption. The results of this study indicate that adsorption with calcined eggshell is a promising, feasible, reliable and ecofriendly method for Remazol textile dye removal from aqueous solutions.
\end{abstract}

Keywords: adsorption, calcined eggshell, Remazol Brilliant Red F3B, Remazol Brilliant Blue R

\section{Introduction}

Water is the source of life and energy, however, millions of people all around the world are experiencing the scarcity of clean and drinkable water [1]. Textile industries wastewaters have complex composition, their exposure to nature in large quantities involve complicated cleaning technologies, especially if the contaminants are at low concentrations, generally these treatments are associated with high costs, therefore their practical application impossible. These facts justify researches for finding out alternative methods that are more effective, advantageous and low cost [2]. It is reported that over 50,000 tonnes of dye, containing hazardous, carcinogenic mutagenic substances that can damage life (aquatic, human and vegetal), are discharged via effluent into the environment annually [3]. Generally, reactive dyes contain functional groups like azo, phthalocyanine, anthraquinone, formazane, and oxazine as chromophore. During the dyeing process, whn exposed to heat and alkaline conditions, the dye's reactive sites interact with the functional groups of the fiber. During the dying procedure of reactive dyes a large amount of the applied dye is wasted because it is hydrolyzed to some extent, and therefore they are inactivated by this competing hydrolysis reaction. Compared with other dyes, reactive dyes represent severe pollutants [4]. Remazol Brilliant Red (RR) and Remazol Brilliant Blue F3B (RB) are reactive dyes, frequently used as a starting material in the production of polymeric dyes. They represent an important class of toxic and recalcitrant organopollutants. They consist of a chromophore and a functional group that binds the dyestuff to the

*email: tonk.szende@sapientia.ro 
fiber [5]. Adsorption as a water cleaning method has been found to be more favorable than other treatments due to its low cost, simplicity of design, ease of operation, and insensitivity of toxic substance [6]. Recently, many researchers have focused on finding low cost and available adsorbents from agricultural, industrial, household wastes: green tea [7], sandpaper waste [8], corn cob [9], sawdust [10-12], microcline particles [13], bentonite [14-16], agricultural waste [17-19], brown alga [20], soy bean and mustard husk [21], wheat bran [22], wood fiber [23]. Eggshell was also used as a possible adsorbent for cyanide, heavy metal, phenol, phosphate, pharmaceutical antibiotics and dye removal [24-31,31-34]. Eggs represent a major ingredient in a large variety of food products such as cakes, salad dressings and fast foods, the production of which results in several daily tons of eggshell waste and incur considerable disposal costs in the world [35]. Therefore, eggshell waste is available in huge quantities from the food processing, egg breaking, and hatching industries. About 250,000 tons of eggshell waste is produced annually worldwide by the food processing industry only [36]. Around $40 \%$ of egg production originates in the developing countries, with only $20 \%$ produced in the developed world. Global egg production in 2010 was around 69 million tons [37]. The problem is that this huge amount of waste is highly hazarous and is hard to get rid of. When disposing it to landfill, eggshell, rich in protein, attracts rats, bugs and bacteria that can infect the soil. The messy holding containers in which eggshell waste is stored can have an unpleasant odor due to the rotting proteins, which can affect the neighborhood, causing air pollution. Eggshell, having high surface and a porous structure is a very good adsorbent, its efficiency can be intensified by calcinization when exposed to heat, resulting a completely changed main structure.

The aim of this study is not only to clear wastewaters from Remazol Red and Remazol Blue textile dyes, but to use calcined chicken eggshell waste material as an alternative, low cost adsorbent. We studied the effects of the initial parameter changes in order to identify the optimal adsorption parameters, and thus reach the highest efficiency. With the help of equilibrium data, isotherm (Langmuir, Freundlich, Dubinin-Radushkevich and Temkin) and kinetic models were calculated. The surface of eggshell was characterized by SEM images. EDX analysis was used to determine the elemental composition of both dyes and calcined eggshell waste before and after dye (RR, RB) adsorption.

\section{Materials and methods}

\subsection{Preparation of adsorbent}

During the research, used chicken eggshell (Gallus Gallus domesticus) was collected from daily used kitchen rubbish. The surface of the used eggshell was thoroughly washed both with tap water and MilliQ water to remove pollutants. The clean eggshell was dried at $85^{\circ} \mathrm{C}$ in a Memmert UN75PLUS drying cabinet, than shredded and shieved. The eggshell of the desired particle size $(160 \mu \mathrm{m})$ was than calcined at $1000{ }^{\circ} \mathrm{C}$ for 4 hours with a Nabertherm $30-3000^{\circ} \mathrm{C}$ oven. In our previous study on Remazol Brilliant Violet-5R dye adsorption with calcined eggshell we investigated the thermogravymetric parameters of the eggshell, thus we found that there were two main mass losses when eggshell was exposed to heat, below $800{ }^{\circ} \mathrm{C}$ (here dissapeared the organic compounds and the adsorbed water molecules) and in the range $800-900{ }^{\circ} \mathrm{C}\left(\mathrm{CaCO}_{3}\right.$ was transformed into $\left.\mathrm{CaO}\right)$. With the help of BET model (for $S_{t}$ ) and Dollimore - Heal method (for $\left.V_{p}\right)$ we determined the surface area $\left(S_{t}=3 \mathrm{~m}^{2} / g\right.$ ) and pore volume $\left(\mathrm{V}_{\mathrm{p}}=0.015 \mathrm{~cm}^{3} / \mathrm{g}\right)$ of calcined eggshell [25].

\subsection{Dye solution}

Analytical grade Remazol Brilliant Red F3B (RR) and Remazol Brilliant Blue R (RB) was bought from DyeStar Singapore Pte. Ltd. and was used without any further purification. A stock solution of 1 $\mathrm{g} / \mathrm{L}$ was diluted when needed for experiments. During adsorption studies the concentration of RR and RB dyes from different samples was determined using a UV-Vis spectrophotometer (Agilent Cary 60 UV-VIS). Chemical structures and characteristics of RR and RB dyes are summarized in Table 1. 
Table 1. Dye characteristics

\begin{tabular}{|c|c|c|}
\hline & Remazol Brilliant Red F3B (RR) & Remazol Brilliant Blue R (RB) \\
\hline Chemical formula & $\mathrm{C}_{29} \mathrm{H}_{19} \mathrm{~N}_{3} \mathrm{Na}_{4} \mathrm{O}_{17} \mathrm{~S}_{5}$ & $\mathrm{C}_{22} \mathrm{H}_{16} \mathrm{~N}_{2} \mathrm{Na}_{2} \mathrm{O}_{11} \mathrm{~S}_{3}$ \\
\hline Molar mass & $933.76 \mathrm{~g} / \mathrm{mol}$ & $626.53 \mathrm{~g} / \mathrm{mol}^{2}$ \\
\hline Max. absorbance & $539 \mathrm{~nm}$ & $592 \mathrm{~nm}$ \\
\hline Color index number & 181055 & 61200 \\
\hline
\end{tabular}

\subsection{Optimization of initial conditions for adsorption}

The biosorption experiment was carried out in $250 \mathrm{~mL}$ Erlenmeyer flasks with $100 \mathrm{~mL}$ dye solution and calcined eggshell (the amount varied with condition). Batch equilibrium technique was used to determine the adsorption, where the suspension of calcined eggshell and dye solution was agitated in a rotary shaker at $700 \mathrm{rpm}$ at room temperature, until equilibrium was reached. Various factors can affect the removal of RR and RB from wastewater by adsorption, therefore it is necessary to find the optimal initial conditions (such as initial dye concentration, biomass weight, $\mathrm{pH}$ ) to reach maximum adsorption capacity and efficiency. The studied initial parameter changes of RR and RB dye adsorption on calcined chicken eggshell are summarized in Table 2.

Table 2. Initial parameter changes

\begin{tabular}{|c|c|c|c|c|c|c|}
\hline & $\mathbf{C}_{\mathbf{i}}(\mathbf{m g} / \mathbf{L})$ & $\mathbf{m}(\mathbf{g})$ & $\mathbf{p H}$ & $\mathbf{T}^{\mathbf{}} \mathbf{C}$ & Agitation speed & Particle size \\
\cline { 1 - 4 } Dye concentration & $20-100$ & 1.5 & 7 & & & \\
\cline { 1 - 5 } Biomass weight & 20 & $0.5-2$ & 7 & \multirow{2}{*}{$20 \pm 0.5^{\circ} \mathrm{C}$} & $700 \mathrm{rpm}$ & $160 \mu \mathrm{m}$ \\
\cline { 1 - 5 } $\mathbf{p H}$ & 20 & 1.5 & $3,5,7,9$ & & & \\
\hline
\end{tabular}

\subsection{Analytical measurements}

The surface of calcined chicken eggshell before and after adsorption (the calcined eggshell was kept in $1 \mathrm{~g} / \mathrm{L}$ dye solution for 3 hours) and dye powder (RR, RB) was studied by JEOL (USA) JSM 5510 LV SEM scanning electron microscopy at various magnifications.

The same samples were further analyzed with Scanning Jeol JEM 5510 JV and Oxford Instruments EDS Analysis System Inca 300 (UK) in order to determine the elemental composition of control and dye adsorbed by calcined eggshell. As in our previous studies, enrichment factors helped in seeing the distribution of the elements.

\section{Results and discussions}

\subsection{Effect of initial dye concentration}

The effect of initial dye concentration relies on the immediate relation between the dye concentration and the available binding sites on the adsorbent surface [38]. Initial concentration provides an important driving force to overcome all mass transfer resistances of the dye between the aqueous and solid phases, therefore higher concentration can increase the adsorption [39]. In order to study the effect of dye concentration on calcined eggshell surface, experiments were carried out using a fixed amount of adsorbent $(1.5 \mathrm{~g})$, a stirring rate of $700 \mathrm{rpm}$ without $\mathrm{pH}$ adjustment, but varying the 
initial dye concentration between $20-100 \mathrm{mg} / \mathrm{L}$, as shown in Figure1. All values are the means and standard errors of nine parallel results. Both for RR and RB we achieved an efficiency that was higher than $97 \%$, regardless of dye concentration. However, adsorption equilibrium was reached in 90 minutes. A similar trend was observed in the case of Remazol Brilliant Violet-5R dye, under same initial conditions with calcined eggshell $(\mathrm{E}=90 \%)$. The adsorption capacity increased with the increase of dye concentration, which can be explained with the high driving force for mass transfer at a high initial dye concentration [40].
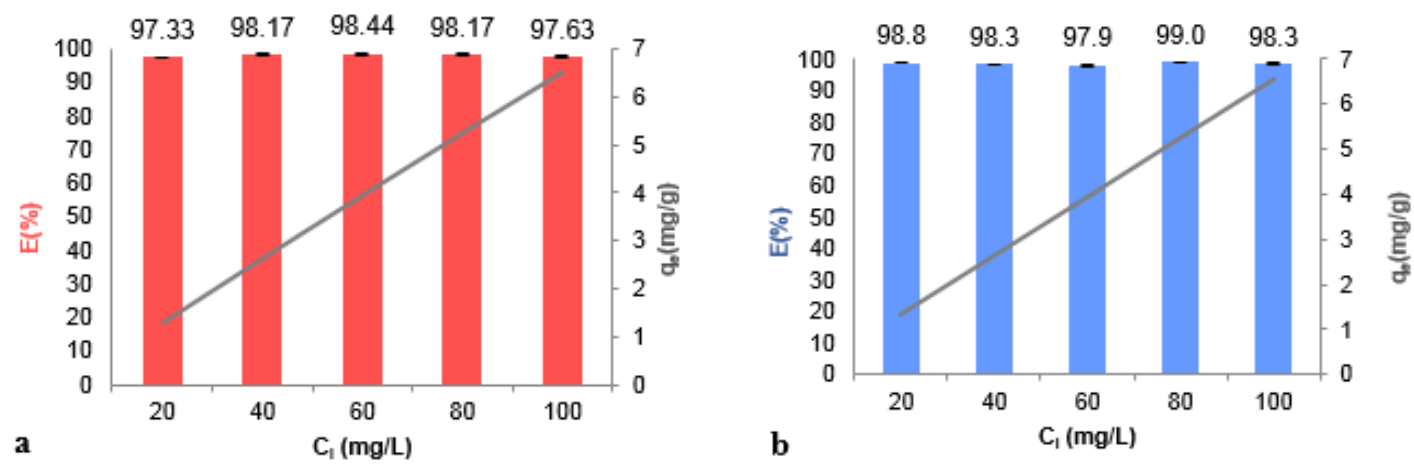

Figure 1. Influence of the initial (a) RR and (b) RB dye concentration on the adsorption capacity and removal efficiency on calcined eggshell powder; $\mathrm{C}_{\mathrm{i}}=20-100 \mathrm{mg} / \mathrm{L}$, $1.5 \mathrm{~g}$ biomass, $700 \mathrm{rpm}, p \mathrm{H}=7.0 \pm 0.2, \mathrm{~T}=20 \pm 0.5{ }^{\circ} \mathrm{C}$

\subsection{Effect of adsorbent dosage}

The effect of calcined eggshell dosage on RR and RB dye removal was evaluated using $0.5 ; 1 ; 1.5$; $2 \mathrm{~g}$ of adsorbent with both textile dye, constant parameters being $\mathrm{C}_{\mathrm{i}}=20 \mathrm{mg} / \mathrm{L}, 700 \mathrm{rpm}, \mathrm{pH}$ unadjusted, $\mathrm{T}=20 \pm 0.5{ }^{\circ} \mathrm{C}$. From the results (Figure 2), it can be inferred that RR dye had the highest adsorption efficiency in case of $1 \mathrm{~g}$ adsorbent, where $\mathrm{E}=97.83 \%$, whereas in case of $1.5 \mathrm{~g}$ adsorbent we got $\mathrm{E}=97.33 \%$. We can see a trend of - mainly constant - decrease. On the other hand, RB dye adsorption was highest when adsorbed with $1.5 \mathrm{~g}$ calcined eggshell $(\mathrm{E}=98.83 \%)$, smallest $(\mathrm{E}=92 \%)$, when $0.5 \mathrm{~g}$ calcined eggshell was added to dye solution. Due to increase in surface area when more adsorbent was added, higher efficiency was achieved, but after all pores were bounded by dye molecules, there was no need for further amount increase.
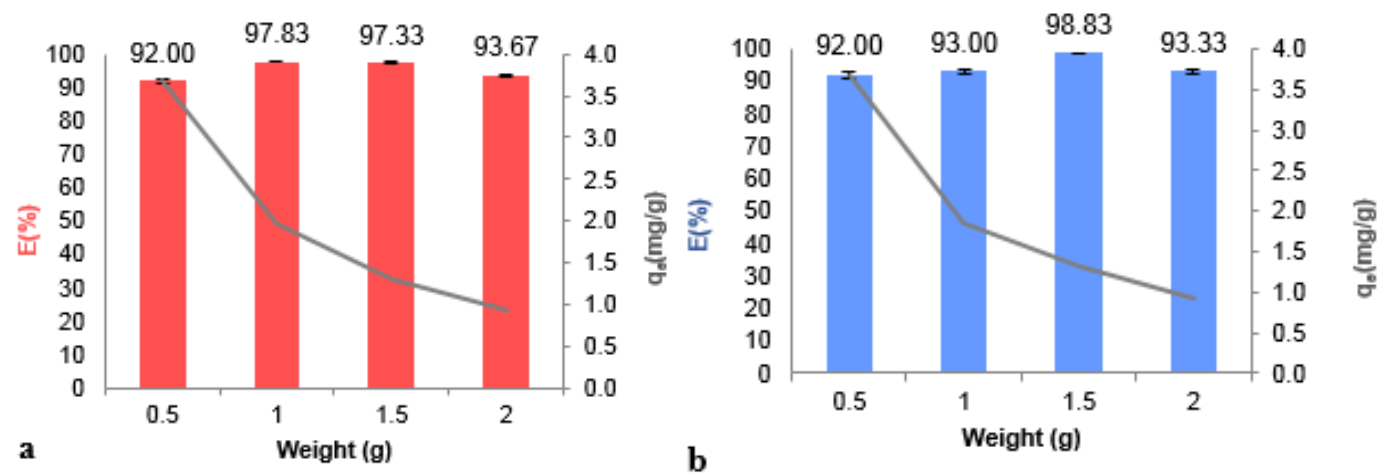

Figure 2. Influence of adsorbent dosage for (a) RR and (b) RB dye on the adsorption apacity and removal efficiency on calcined eggshell powder; $\mathrm{C}_{\mathrm{i}}=20 \mathrm{mg} / \mathrm{L}, 0.5-2 \mathrm{~g}$ biomass, $700 \mathrm{rpm}, \mathrm{pH}=7.0 \pm 0.2, \mathrm{~T}=20 \pm 0.5^{\circ} \mathrm{C}$

\subsection{Effect of solution $p \mathbf{H}$}

The $p \mathrm{H}$ of the solution is a very important parameter in the adsorption process, particularly for dye adsorption. The magnitude of electrostatic charges, which are imparted by the ionized dye molecules, is controlled by the solution $p \mathrm{H}$. As a result, the rate of adsorption will vary with the $p \mathrm{H}$ of the medium used $[38,41]$. As previous studies prove, for cationic dyes the percentage removal is higher at high 
solution $p \mathrm{H}$, whereas the efficiency of adsorption increases with $p \mathrm{H}$ decrease for anionic dyes $[39,42-$ 44]. RR and RB being reactive dyes, thus anionic, the adsorption is preferable in acidic conditions. The effect of $\mathrm{pH}$ was investigated on the adsorption of $\mathrm{RR}$ and $\mathrm{RB}$ dyes on the surface of calcined eggshell. For this study the $\mathrm{pH}$ of aqueous dye solution was adjusted with $0.1 \mathrm{~N} \mathrm{NaOH}$ and $0.1 \mathrm{~N} \mathrm{HCl}$. In batch conditions, after the desired $\mathrm{pH}$ was reached, calcined eggshell was added to the solution. Calcined eggshell is the product of $\mathrm{CaCO}_{3}$; therefore, it changed the $\mathrm{pH}$ to basic when it was added to the dye solution. Amarasinghe and Wanniarachchi (2019) reported that after calcination (in raw eggshell the $\mathrm{CaCO}_{3}$ transformed to $\mathrm{CaO}$ ) when exposed to the atmosphere $\mathrm{CaO}$ converted to $\mathrm{Ca}(\mathrm{OH})_{2}$, dissolving it in water solution gives it a basic character [45]. This is the reason why the efficiency results in Figure 3 are almost identical. Highest adsorption efficiency was achieved for both dyes at $p \mathrm{H}=3\left(\mathrm{E}_{\mathrm{RR}}=98.33 \% ; \mathrm{E}_{\mathrm{RB}}=99 \%\right)$.

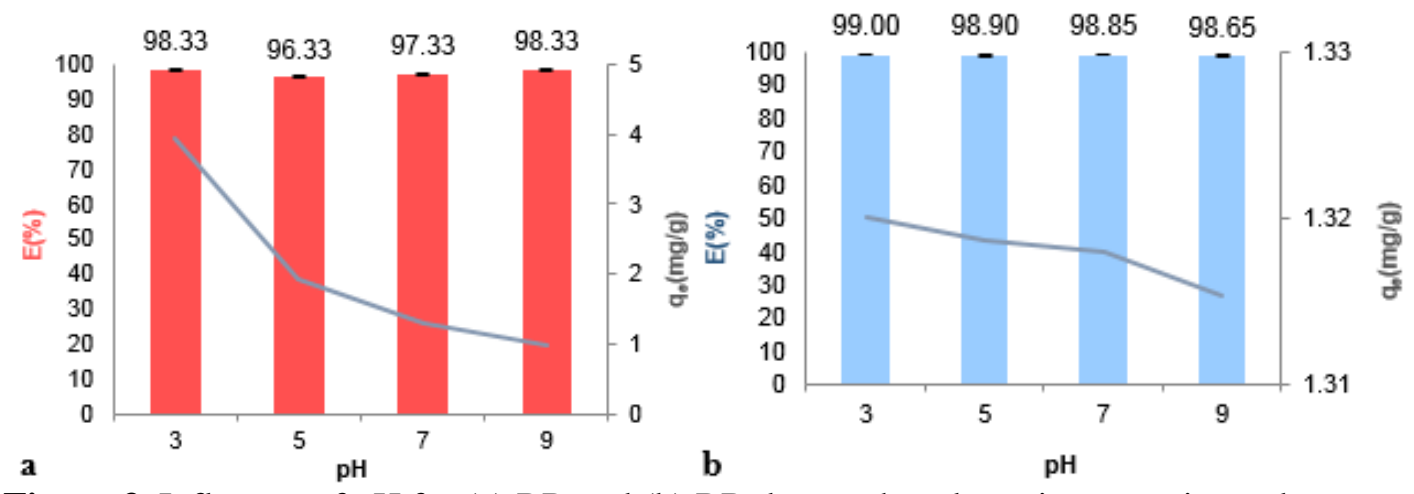

Figure 3. Influence of $p \mathrm{H}$ for (a) $\mathrm{RR}$ and (b) $\mathrm{RB}$ dye on the adsorption capacity and removal efficiency on calcined eggshell powder; $\mathrm{C}_{\mathrm{i}}=20 \mathrm{mg} / \mathrm{L}, 0.5-2 \mathrm{~g}$ biomass, $700 \mathrm{rpm}, p \mathrm{H}=3.0-9.0 \pm 0.2, \mathrm{~T}=20 \pm 0.5^{\circ} \mathrm{C}$

\subsection{Adsorption isotherm and kinetics studies}

Adsorption isotherms give information about the nature of interaction between adsorbent (calcined eggshell) and adsorbate (RR, RB dye), such as the properties of adsorbent surface and its affinity to the adsorbate [6]. In Table 3 the calculated parameters of Langmuir, Freundlich, Dubinin-Radushkevich and Temkin isotherm models are listed. As shown in Table 3, the linear regression coefficient of RR is highest $\left(\mathrm{R}^{2}=0.988\right)$ in the case of the Dubinin-Radushkevich isotherm model. The D-R model is an empirical adsorption model, which presumes a multilayer character, where Van der Waal's forces occur between the adsorbent (calcined eggshell) and adsorbate (RR dye). It is applicable for physical adsorption processes and describes the adsorption on microporous adsorbents [46]. On the other hand, in case of RB dye the Langmuir isotherm model shows better fitness, $\mathrm{R}^{2}$ being 0.987 . This isotherm model indicates that the adsorption occurs monolayer on calcined eggshell surface, and it is reversible. As the concentration of the adsorptive increases, the number of binding sites decreases exponentially. The adsorbent has a homogeneous surface, with adsorption centers of equal strength, and a constant number of binding sites, that can be occupied by only one molecule. In our experimental conditions, the adsorption is physical in nature for both dyes, which is proven by the fact that the Temkin constant $\left(\mathrm{B}_{\mathrm{RR}}=3 \times 10^{-5} \mathrm{~J} / \mathrm{mol}, \mathrm{B}_{\mathrm{RB}}=5 \times 10^{-5} \mathrm{~J} / \mathrm{mol}\right)$ is less than $20 \mathrm{~kJ} / \mathrm{mol}[47]$.

Table 3. Langmuir, Freundlich, Dubinin-Radushkevich and Temkin calculated coefficients for RR and RB adsorption on calcined eggshell; $\mathrm{C}_{\mathrm{i}}=20-100 \mathrm{mg} / \mathrm{L}, 1.5 \mathrm{~g}$ biomass, $700 \mathrm{rpm}$, $p \mathrm{H}=7.0 \pm 0.2, \mathrm{~T}=0 \pm 0.5^{\circ} \mathrm{C}, \mathrm{V}=100 \mathrm{~mL}$

\begin{tabular}{|c|c|c|c|c|c|c|c|c|c|c|c|c|}
\hline & \multicolumn{3}{|c|}{ Langmuir } & \multicolumn{3}{|c|}{ Freundlich } & \multicolumn{3}{|c|}{ Dubinin-Radushkevich } & \multicolumn{3}{|c|}{ Temkin } \\
\hline & $\begin{array}{c}\mathrm{K}_{\mathrm{L}} \\
(\mathrm{I} / \mathrm{mg})\end{array}$ & $\begin{array}{c}q_{\max } \\
(\mathrm{mg} / \mathrm{g})\end{array}$ & $\mathbf{R}^{2}$ & $\mathrm{n}$ & $\begin{array}{c}K_{f} \\
\left(m g^{(1-1 / n) \mid 1 / n / g)}\right.\end{array}$ & $\mathbf{R}^{2}$ & $\begin{array}{c}\beta \\
\left(\mathrm{mol}^{2}\right. \\
\left.\mathrm{kJ}^{2}\right)\end{array}$ & $\begin{array}{c}E \\
(\mathrm{~kJ} / \mathrm{mol})\end{array}$ & $\mathbf{R}^{2}$ & $\begin{array}{l}A_{T} \\
(I / g)\end{array}$ & $\begin{array}{c}\text { B } \\
(\mathrm{J} / \mathrm{mol})\end{array}$ & $\mathbf{R}^{2}$ \\
\hline RR & 0.710 & 10.87 & 0.880 & 0.987 & 3.251 & 0.879 & $3 \times 10^{-13}$ & 1291 & 0.988 & 2.4 & $3 \times 10^{-5}$ & 0.282 \\
\hline
\end{tabular}




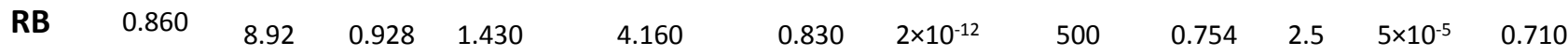

The adsorption mechanism was further analyzed by Lagergren's pseudo-first- and Ho's and McKay pseudo-second-order kinetic models. The specific kinetic parameters were calculated and are listed in Table 4 and 5 separately for RR and RB dyes. From the tables below we can see that for both dyes constant values of McKay pseudo-second-order kinetic models showed the best fit of experimental data $\mathrm{R}^{2}$ values being close to 1 . Moreover, the calculated capacity values correspond to the ones achieved in the experiments.

The quantity in equilibrium from experiments $\mathrm{q}_{\mathrm{e}}(\exp )$ is very close or similar to the quantity in equilibrium calculated $\mathrm{q}_{\mathrm{e}}(\mathrm{calc})$ value from the, this shows the adequacy of experimental measurement data to pseudo-second-order kinetic model [48].

Table 4. Pseudo-first-order and pseudo-second-order constants, for RR adsorption on calcined eggshell using different initial concentrations; $\mathrm{C}_{\mathrm{i}}=20-100 \mathrm{mg} / \mathrm{L}, 1.5 \mathrm{~g}$ biomass, $700 \mathrm{rpm}$, $p \mathrm{H} 7.0 \pm 0.2, \mathrm{~T}=20 \pm 0.5^{\circ} \mathrm{C}, \mathrm{V}=100 \mathrm{~mL}$

\begin{tabular}{|c|c|c|c|c|c|c|c|}
\hline \multicolumn{2}{|c|}{$R R$} & \multicolumn{3}{|c|}{ Pseudo-first-order } & \multicolumn{3}{|c|}{ Pseudo-second-order } \\
\hline C & $q_{e}(\exp )$ & $\mathbf{k}_{1}$ & $q_{e}$ (calc) & & $\mathbf{k}_{2}$ & $q_{e}$ (calc) & \\
\hline (mg/L) & $(\mathrm{mg} / \mathrm{g})$ & (1/min) & (mg/g) & $\mathbf{R}^{2}$ & (g/mg $\times$ min) & (mg/g) & $\mathbf{R}^{2}$ \\
\hline 20 & 1.30 & 0.04 & 1.05 & 0.373 & 6.88 & 1.30 & 1 \\
\hline 40 & 2.62 & 0.13 & 0.60 & 0.526 & 5.58 & 2.62 & 1 \\
\hline 60 & 3.94 & 0.11 & 0.36 & 0.410 & 0.47 & 0.95 & 0.984 \\
\hline 80 & 5.24 & 0.10 & -0.28 & 0.435 & 1.39 & 5.26 & 1 \\
\hline 100 & 6.51 & 0.33 & -0.71 & 0.566 & 1.80 & 6.54 & 0.999 \\
\hline
\end{tabular}

Table 5. Pseudo-first-order and pseudo-second-order constants, for RB adsorption on calcined eggshell using different initial concentrations; $\mathrm{C}_{\mathrm{i}}=20-100 \mathrm{mg} / \mathrm{L}, 1.5 \mathrm{~g}$ biomass, $700 \mathrm{rpm}$, $p \mathrm{H}=7.0 \pm 0.2, \mathrm{~T}=20 \pm 0.5^{\circ} \mathrm{C}, \mathrm{V}=100 \mathrm{~mL}$

\begin{tabular}{|c|c|c|c|c|c|c|c|}
\hline \multicolumn{2}{|c|}{$R B$} & \multicolumn{3}{|c|}{ Pseudo-first-order } & \multicolumn{3}{|c|}{ Pseudo-second-order } \\
\hline $\mathbf{C}$ & $q_{e}(\exp )$ & $\mathbf{k}_{1}$ & $q_{e}$ (calc) & & $\mathbf{k}_{2}$ & $q_{e}$ (calc) & \\
\hline (mg/L) & $(\mathrm{mg} / \mathrm{g})$ & $(1 / \min )$ & (mg/g) & $\mathbf{R}^{2}$ & (g/mg×min) & (mg/g) & $\mathbf{R}^{2}$ \\
\hline 20 & 1.32 & 0.35 & 0.37 & 0.808 & 9.70 & 1.32 & 1 \\
\hline 40 & 2.62 & 0.14 & 0.36 & 0.578 & 3.66 & 2.62 & 1 \\
\hline 60 & 3.92 & 0.46 & -1.22 & 0.857 & 0.58 & 1.25 & 0.999 \\
\hline 80 & 5.28 & 0.04 & -1.25 & 0.759 & 0.43 & 5.29 & 1 \\
\hline 100 & 6.56 & 0.13 & -0.09 & 0.862 & 0.23 & 6.59 & 1 \\
\hline
\end{tabular}

\subsection{SEM analysis}

The surface morphology, characterization of RR, RB dyes, calcined eggshell before and after adsorption was studied by SEM analyses. As seen in Figure 4a, calcined eggshell has a heterogenous, irregularly shaped, porous structure. After adsorption (Figure 4b, c) the interaction between calcined eggshell and the dyes resulted in the disappearance of irregularly shaped forms, dye saturated pores, the appearance of aggregates in surface, therefore the whole structure, surface of calcined eggshell changed due to biosorption. 

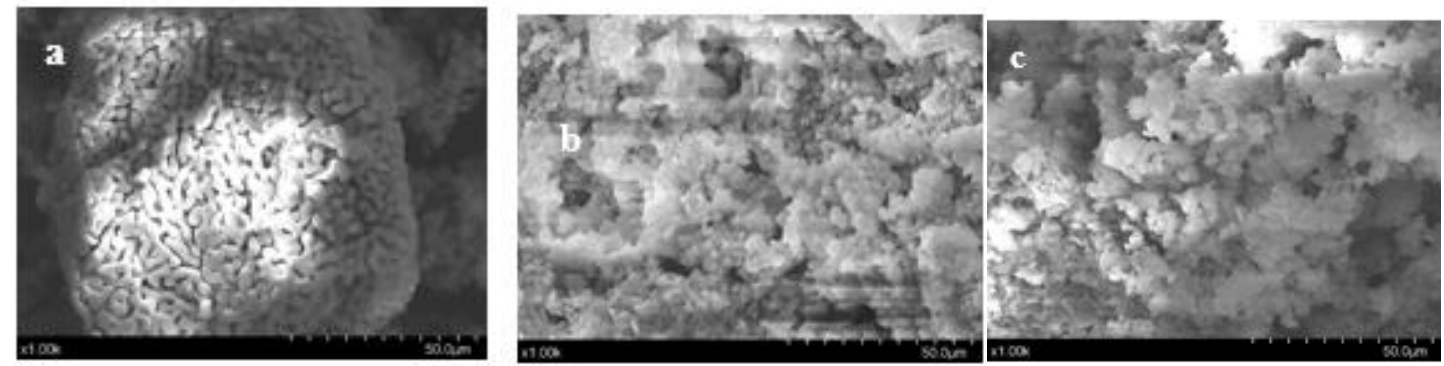

Figure 4. SEM photographs of (a) control (b) RR and (c) RB adsorbed calcined eggshell waste

\subsection{EDX analyses}

EDX measurements help to identify the elemental composition of both dyes and eggshell before and after adsorption. The adsorbent contains mostly $\mathrm{Ca}(59 \%)$ and $\mathrm{O}(36 \%)$, it was expected due to calcination process, where $\mathrm{CaCO}_{3}$ becomes $\mathrm{CaO}$ and $\mathrm{CO}_{2}$ when exposed to heat $\left(1000{ }^{\circ} \mathrm{C} 4\right.$ hours) however, small percentage of $\mathrm{C}, \mathrm{N}$ and $\mathrm{Mg}$ remained in the samples (maybe from organic matter or $\mathrm{MgCO}_{3}$ ). As the structure of the dyes (Table 6) showed $\mathrm{C}, \mathrm{O}, \mathrm{Na}$ and $\mathrm{S}$ are the fundamental building blocks of the RR dye and $\mathrm{O}, \mathrm{C}, \mathrm{Na}, \mathrm{S}$ and $\mathrm{N}$ are the main constituents of RB dye. In both cases we observe the decrease of $\mathrm{Ca}$, the increase of $\mathrm{C}, \mathrm{O}$ due to dissolution after dye adsorption and the appearance in small quantities of $S$ (appears in the dye content respectively to $R R, R B$ dyes), this indicates the binding of dye molecules into calcined eggshell surface.

Table 6. EDX spectra of control, dye treated calcined eggshell and RR, RB dyes; values are the means of 10 replicates (results not necessarily have quantitative purpose, trace amounts have just a qualitative role)

\begin{tabular}{cccccc}
\hline Elements & $\begin{array}{c}\text { Wt(\%) Content of the } \\
\text { control eggshell }\end{array}$ & $\begin{array}{c}\text { Wt(\%) Content of Wt(\%) Content of the } \\
\text { R-Red dye }\end{array}$ & $\begin{array}{c}\text { Wgt(\%) Content of adsorption of } \\
\text { R-Red }\end{array}$ & $\begin{array}{c}\text { Wt(\%) Content of the } \\
\text { eggshell adsorption of } \\
\text { R-Blue dye }\end{array}$ & $\begin{array}{c}\text { R-Blue } \\
\text { Rshell }\end{array}$ \\
\hline $\mathbf{C a}$ & $59.63 \pm 14.81$ & $0.02 \pm 0.007$ & $31.79 \pm 4.39$ & $0.06 \pm 0.02$ & $42.26 \pm 5.78$ \\
$\mathbf{O}$ & $35.97 \pm 14.16$ & $31.12 \pm 2.41$ & $52.10 \pm 2.06$ & $36.36 \pm 7.82$ & $47.52 \pm 1.76$ \\
$\mathbf{C}$ & $3.33 \pm 1.94$ & $49.89 \pm 4.54$ & $15.27 \pm 3.41$ & $29.19 \pm 7.58$ & $9.31 \pm 4.69$ \\
$\mathbf{M g}$ & $0.76 \pm 0.27$ & $0.02 \pm 0.02$ & $0.39 \pm 0.21$ & $0.03 \pm 0.01$ & $0.50 \pm 0.04$ \\
$\mathbf{N}$ & $0.32 \pm 0.37$ & $0.07 \pm 0.16$ & 0 & $0.89 \pm 0.40$ & 0 \\
$\mathbf{N a}$ & 0 & $8.43 \pm 1.95$ & $0.13 \pm 0.06$ & $14.27 \pm 3.38$ & $0.07 \pm 0.03$ \\
$\mathbf{S}$ & 0 & $8.67 \pm 0.67$ & $0.29 \pm 0.07$ & $9.19 \pm 3.15$ & $0.19 \pm 0.03$ \\
\hline
\end{tabular}

\subsection{Bioconcentration factor $(\mathrm{BCF})$}

The bioconcentration factor provides information about the number of how many times the adsorbent accumulates the dye (RR, RB) concentration. This value was calculated based on equilibrium data and is the ratio of dye concentration in adsorbent and dye concentration in aqueous solution. The BCF was determined for five different dye concentrations (Figure 5). In each case BCF was higher than 3, meaning that calcined eggshell has high bioaccumulation tendency for Remazol dyes $[24,25]$.

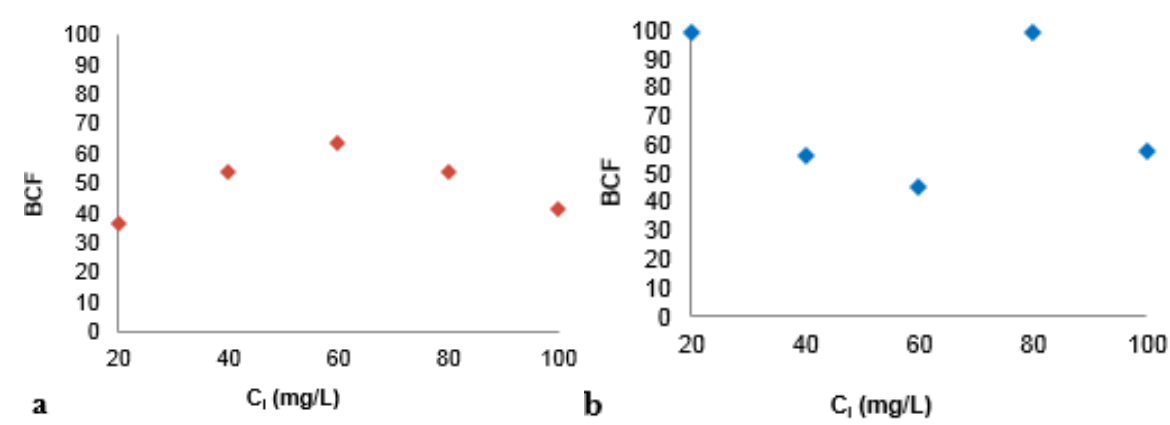

Figure 5. BCF values for (a) RR and (b) RB dyes in calcined eggshell waste at different concentrations 


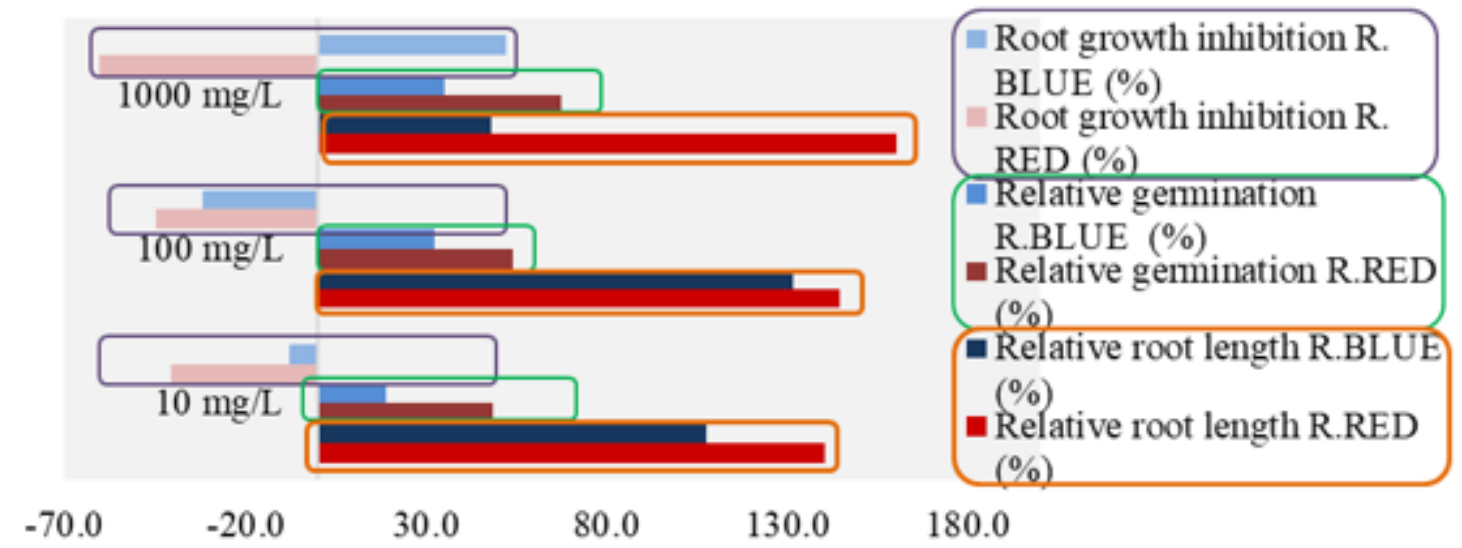

Figure 6. Seedling growth test result

\subsection{Seed germination toxicology test}

An ecotoxicological, seedling growth test was carried out based on Hungarian standards (MSZ 21978/8-85) in order to investigate the effect of RR and RB textile dyes on lettuce (Lactuca sativa) seed inhibition [26]. Figure 6 contains the root growth inhibition (RGI\%), relative germination (RG\%) and relative rooth length (RRL\%), values for both dyes under different concentrations (10-100-1000 $\mathrm{mg} / \mathrm{L})$. When exposed to different concentrations of RR dye, lettuce seed shows root simulation due to high nitrogen, sulphur content of the dye. This tendency can be observed in figure 6 , because root growth inhibition varies from -40 to $-60 \%$ as a result of concentration growth. In case of RB at lower concentrations $(10,100 \mathrm{mg} / \mathrm{L})$ the root length grows (RGI=7.6 and 31.8\%), whereas at high concentration the dye inhibits the root growth by $52 \%$. In all cases, the number of germinated seeds decreased compared to the control sample. However, as the concentration increased, the number of germinated seeds increased, too; thus, the RG (RR:49 to 68\%; RB:19 to 35\%) showed a similar tendency with the concentration. The RRL of samples in RR dye increase with the increase of dye concentration.

\section{Conclusions}

Based on our results, eggshell in calcined form has proved to be an effective adsorbent for the purification of artificially contaminated aqueous solutions by removing both reactive textile dyes (Remazol Brilliant Red F3B, Remazol Brilliant Blue R).

As studying the initial parameter changes, we can conclude that:

-We reached more than $97 \%$ efficiency in case of initial concentration change.

-Adsorption efficiency was highest when using $1 \mathrm{~g}$ calcined eggshell in case of $\mathrm{RR}(\mathrm{E}=97.83 \%)$ and $1.5 \mathrm{~g}$ in case of $\mathrm{RB}(\mathrm{E}=98.83 \%)$ dyes, whereas, $0.5 \mathrm{~g}$ proved to be the less efficient with $92 \%$ for both dyes.

-pH being a very influential factor described in many adsorption studies, here proved to be not rate determining. This can be explained with the fact that calcined eggshell is basic and therefore after adding it to the $p \mathrm{H}$ adjusted dye solution merely similar $\mathrm{pH}$ was obtained. Nevertheless, the efficiency was highest at $p \mathrm{H}=3$ for both dyes $\left(\mathrm{E}_{\mathrm{RR}}=98.33 \%, \mathrm{E}_{\mathrm{RB}}=99 \%\right)$ where the standard deviation regarding $\mathrm{pH}$ change was 0.83 for RR and 0.15 for RB dye.

In the case of Remazol Brilliant Blue $\mathrm{R}$ textile dye, the isotherm models demonstrate that the adsorption is physical, as the results fit well with the Langmuir isotherm model. Remazol Brilliant Red F3B dye has the highest linear regression coefficient for the Dubinin-Radushkevich isotherm model, so under our experimental conditions this model is the most representative of the adsorption process.

The kinetics of both dyes are best described by the pseudo-second order kinetic model, with both the Remazol Brilliant Red F3B and Remazol Brilliant Blue R dyes achieving linear regression coefficients $\left(\mathrm{R}^{2}\right)$ of 1 at the concentrations tested. 
Scanning electron microscopy images show that the surface of the calcined eggshell undergoes a change after dyeing, and the porous structure of the eggshell is saturated due to the adsorption of clothes dye molecules on the surface of the eggshell.

Based on the EDX measurements, due to dissolution after dye adsorption the amount of $\mathrm{Ca}$ decreased, $\mathrm{C}, \mathrm{O}$ increased, and small quantities of $\mathrm{S}$ appeared proving the calcined eggshells dye adsorption ability.

It can be stated that the initial dye concentration was the most influential factor of the adsorption efficiency, the efficiency increased to a saturated state by increasing the amount of the adsorbent.

Acknowledgement. This research was funded by Sapientia Hungarian University of Transylvania, Romania, Bálint Balassi - Klebelsberg Kuno Scholarship Program, Hungary and Szent István University (NKFIH-1159-6/2019), Hungary.

\section{References}

1.REHMAN, R., SALARIYA, B., MITU, L., Rev. Chim., 67, 2016, 1333.

2. BOMBOS, D., GANEA, R., MATEI, V., MARINESCU, C., BODNAREV, A., MIHAI, S., NATU, T., TAMAS, I., Rev. Chim., 65, 2014, p. 976.

3. TAN, I. W., AHMAD, A.L., HAMEED, B.H., , J. Hazard. Mater., 154, 2008, p. 337.

4. TRIVEDI, K. N., BORICHA, A. B., BAJAJ, H. C., JASRA, R. V., Rasayan J. Chem., 2, no. 2, 2009, p. 379.

5. SATHISHKUMAR, P., ARULKUMAR, M., PALVANNAN, T., J. Clean. Prod., 22, no. 1, 2012, p. 67.

6. KHASRI, A., JAMIR, M.R.M., AHMAD, M.A., AIP Conf. Proc., 2124, no. 1, 2019, 020055.

7. INDOLEAN, C., BURCĂ, S., MĂICĂNEANU, A., Acta Chim. Slov., 64, no. 2, 2017, p. 513.

8. COŞKUN, Y.İ., AKSUNER, N., YANIK, J., Acta Chim. Slov., 66, no. 2, 2019, p. 402.

9. AHMAD, M.A., BELLO, O.S., AHMAD, M.A., Am. J. Mod. Chem. Eng., 1, no. 1, 2014, p. 1.

10. GARG, V.K., GUPTA, R., BALA YADAV, A., KUMAR, R., Bioresour. Technol., 89, no. 2, 2003, p. 121.

11. NAGY, B., MAICANEANU, A., INDOLEAN, C., BURCA, C., SILAGHI-DUMITRESCU, L., MAJDIK, C., Acta Chim. Slov., 60, no. 2, 2013, p. 263.

12. VIJAYARAGHAVAN, K., WON, S.W., YUN, Y.-S., J. Hazard. Mater., 167, no. 1-3, 2009, p. 790.

13. PERNYESZI, T., FARKAS, R., KOVÁCS, J., Minerals 9, no. 9, 2019, p. 555.

14. FABRYANTY, R., VALENCIA, C., SOETAREDJO, F.E., PUTRO, J.N., SANTOSO, S.P., KURNIAWAN, A., JU, YI-HSU, ISMADJI, S., J. Environ. Chem. Eng., 5, no. 6, 2017, p. 5677.

15. GEORGIEVA, N., YANEVA, Z., DERMENDZHIEVA, D., Water Sci. Technol., 76, no. 5, 2017, p. 1065.

16. HEGEdusova, A., HEgEdÜS, O., TOTH, T., VAllMANNOVA, A., ŠlosÁR, M., MEZEYOVA, I, PERNYESZI, T., Bull. Environ. Contam. Toxicol., 97, 2016.

17. ANASTOPOULOS, I., KYZAS, G.Z., J. Mol. Liq. 200, 2014, p. 381.

18. BANERJEE, S., CHATTOPADHYAYA, M.C., Arab. J. Chem., 10, 2017, p. S1629.

19. DAI, Y., SUN, Q., WANG, W., LU, L., LIU, M., LI, J., YANG, S., SUN, Y., ZHANG, K., XU, J., ZHENG, W., HU, Z., YANG, Y., GAO, Y., CHEN, Y., ZHANG, X., GAO, F., ZHANG, Y., Chemosphere, 211, 2018, p. 235.

20. CAPARKAYA, D., CAVAS, L., Acta Chim. Slov., 55, 2008.

21. HUMELNICU, D., SOROAGA, L.V., ARSENE, C., HUMELNICU, I., OLARIU, R.I., Acta Chim. Slov., 66, no. 2, 2019, p. 326.

22. HAMDAOUI, O., CHIHA, M., Acta Chim. Slov., 54, 2007, p. 407.

23. MUNTEAN, S.G., SIMU, G., SFARLOAGA, P., BOLOGA, C., Rev. Chim., 61, (1), 2010, 70. 
24. TONK, S., MAJDIK, C., SZÉP, R., SUCIU, M., RÁPÓ, E., NAGY, B., NICULAE, G.A., Rev. Chim., 68, 2017, p. 1951.

25. RÁPÓ, E., POSTA, K., SUCIU, M., SZÉP, R., TONK, S., Acta Chim. Slov. 66, no.3, 2019, p. 648. 26. RÁPÓ, E., SZÉP, R., KERESZTESI, Á., SUCIU, M., TONK, S., Acta Chim. Slov., 65, no. 3, 2018, p. 709.

27. ABBAS, R.A., FARHAN, A.A., AL-ANI, H.N.A.A.-A.N.A., NECHIFOR, A.C., Rev. Chim., 70, (4), 2019, 1108.

28. AHMAD, R., KUMAR, R., HASEEB, S., Arab. J. Chem., 5, no. 3, 2012, p. 353.

29. AL-GHOUTI, M.A., KHAN, M., J. Environ. Manage., 207, 2018, p. 405.

30. ARABHOSSEINI, A., Res. Agric. Eng. 64, no. 2, 2018, p. 104.

31. LI, J., NG, D.H.L., MA, R., ZUO, M., SONG, P., Chem. Eng. Res. Des., 126, 2017, p. 123.

32. ELETTA, O.A.A., AJAYI, O.A., OGUNLEYE, O.O., AKPAN, I.C., J. Environ. Chem. Eng. 4, no. 1, 2016, p. 1367.

33. GIRALDO, L., MORENO-PIRAJÁN, J.C., J. Anal. Appl. Pyrolysis, 106, 2014, p. 41.

34. KÖSE, T.E., KIVANÇ, B., Chem. Eng. J., 178, 2011, p. 34.

35. ARABHOSSEINI, A., Res. Agric. Eng., 64, no. 2, 2018, p. 104.

36. VERMA, N., KUMAR, V., BANSAL, M.C., Pol. J. Environ. Stud., 21, no. 2, p. 491.

37. GOMES, M.G., PASQUINI, D., Environ. Prog. Sustain. Energy, 37, no. 6, 2018, p. 2093.

38. TA WEE SEOW, CHI KIM LIM, Int. J. Appl. Eng. Res., 11, no. 4, 2016, p. 2675.

39. AKSU, Z., DÖNMEZ, G., Chemosphere, 50, no. 8, 2003, p. 1075.

40. BULUT, Y., AYDIN, H., Desalination, 194, no. 1, 2006, p. 259.

41. ONAL, Y., AKMIL-BAŞAR, C., EREN, D., SARICI-ÖZDEMIR, Ç., DEPCI, T., J. Hazard. Mater., 128, no. 2, 2006, p. 150.

Manuscript received: 29.10 .2019 